\title{
IDENTIFICATION OF LACTIC ACID BACTERIA FROM BIOFLOK TECHNOLOGY WHICH HAS BEEN GAVE MOLLASES ON RED TILAPIA (Oreochromis sp.) AQUACULTURE
}

\author{
IDENTIFIKASI BAKTERI ASAM LAKTAT (BAL) DARI \\ TEKNOLOGI BIOFLOK YANG DIBERI MOLLASE PADA \\ BUDIDAYA IKAN NILA MERAH (Oreochromis sp.)
}

\author{
Nelli Karolina Sitorus ${ }^{1}$, Iesje Lukistyowati ${ }^{1}$, Henni Syawal ${ }^{1}$, Iskandar Putra ${ }^{1}$ \\ ${ }^{I}$ Budidaya Perairan Fakultas Perikanan dan Kelautan, Universitas Riau, Jl. HR Soebrantas Km 12,5 Simpang Baru, \\ Panam-Pekanbaru, Indonesia 28293-Correspondence Author : NelliKarolinaSitorus@ gmail.com
}

\begin{tabular}{|c|c|}
\hline I N F O A R T I K E L & A B S T R A C T \\
\hline & \multirow[b]{2}{*}{$\begin{array}{l}\text { The aim of this research was to determine the types of lactic acid bacteria from } \\
\text { biofloc technology with the addition of mollase in red tilapia aquaculture containers } \\
\text { and to determine the optimum growth of lactic acid bacteria at } \mathrm{pH} 2,4 \text {, and } 6 \text {, and } \\
\text { also to observe the density of bacteria in the biofloc container water during } \\
\text { maintenance. The methods used in this research are survey and experiments by } \\
\text { taking flok from maintenance container and then identifying the lactic acid bacteria. } \\
\text { The results of lactic acid bacteria inoculation obtained } 16 \text { isolates isolated from floc } \\
\text { which can only grow at pH } 4 \text { and } \mathrm{pH} 6 \text {. Identification based on physical tests, } \\
\text { chemical tests, and biochemical tests showed that the isolates were classified into } \\
\text { Bacillus and Streptococcus. The amount of bacterial density water from containers } \\
\text { of biofloc technology were given mollase during research reached the highest point } \\
\text { in the third week, which averaged } 10^{9} \mathrm{CFU} / \mathrm{mL} \text {. }\end{array}$} \\
\hline $\begin{array}{l}\text { Keywords: } \\
\text { Identification, Lact } \\
\text { Bacteria, Biofloc } \\
\text { technology,red tila } \\
\text { (Oreochromis sp.) }\end{array}$ & \\
\hline
\end{tabular}

\section{PENDAHULUAN}

Budidaya perikanan di Indonesia saat ini sudah berkembang pesat baik kegiatan budidaya yang dilakukan di perairan tawar, laut maupun payau. Seiring kemajuan teknologi, penemuan baru diberbagai bidang sudah dapat kita rasakan termasuk di bidang perikanan salah satunya, yaitu kegiatan budidaya dengan sistem teknologi bioflok. Menurut de Schryver et al. (2008), di dalam flok tersebut terdapat beberapa organisme pembentuk seperti bakteri, plankton, jamur, alga, dan partikel-partikel tersuspensi yang mempengaruhi struktur dan kandungan nutrisi bioflok. Kegiatan budidaya dengan teknologi bioflok memiliki keunggulan dibandingkan yang lainnya karena prinsip utama dari teknologi bioflok, yaitu memanfaatkan bakteri heterotrof maupun autotrof yang dapat mengubah limbah organik (feses dan sisa pakan) yang terdapat dalam wadah budidaya menjadi kumpulan mikroorganisme baik yang tergabung dalam sebuah gumpalan (flok) kemudian dapat dimanfaatkan ikan sebagai pakan tambahan.

Teknologi bioflok bekerja dengan menggunakan bantuan probiotik dan sumber karbon organik. Probiotik yang biasa digunakan untuk meningkatkan pertumbuhan ikan adalah golongan bakteri asam laktat (Flores, 2011). Sifat terpenting dari BAL, yaitu memiliki kemampuan untuk memfermentasi gula menjadi asam laktat, menjaga kesehatan usus, 
membantu penyerapan makanan, dan tumbuh pada $\mathrm{pH}$ rendah sehingga dapat menghambat pertumbuhan bakteri patogen. Setiap bakteri asam laktat memerlukan kondisi lingkungan $\mathrm{pH}$ optimum yang berbeda untuk dapat tumbuh secara optimum (Smid dan Gorris, 2007). Teknologi bioflok juga dilakukan dengan menambahkan sumber karbon ke dalam media pemeliharaan untuk merangsang pertumbuhan bakteri. Salah satu sumber karbon yang dapat digunakan, yaitu mollase.

Teknologi bioflok merupakan salah satu teknologi yang tepat untuk pemeliharaan ikan nila merah secara intensif karena sifat ikan nila yang mampu hidup dengan kepadatan tinggi, memiliki toleransi yang luas terhadap kondisi lingkungan dan, ikan nila juga dapat memakan komunitas bakteri yang terdapat dalam flok sehingga terjadi penghematan biaya pakan. Selain itu, sistem teknologi bioflok juga mampu meningkatkan sistem imun pada ikan tilapia (Azim et al., 2007). Menurut Mulyana (2011), dengan adanya sistem teknologi bioflok berbagai keuntungan dapat diperoleh petani diantaranya waktu pemeliharaan relatif singkat sehingga ikan bisa cepat panen, memperbaiki kualitas air, memperbaiki efisiensi pakan, dan dapat meningkatkan daya tahan tubuh ikan terhadap serangan berbagai penyakit.

Penelitian ini bertujuan untuk mengetahui jenis bakteri asam laktat apa saja yang terdapat pada teknologi bioflok, untuk mengetahui $\mathrm{pH}$ pertumbuhan bakteri asam laktat yang optimum, dan untuk mengetahui jumlah kepadatan bakteri air dalam wadah budidaya bioflok selama masa pemeliharaan.

\section{METODE PENELITIAN}

Penelitian dilaksanakan pada bulan April sampai Juni 2018 di Laboratorium Parasit dan Penyakit Ikan Jurusan Budidaya Perairan Fakultas Perikanan dan Kelautan Universitas Riau.

Metode yang digunakan dalam penelitian ini adalah metode survei dan eksperimen dengan mengambil flok dari wadah pemeliharaan kemudian mengidentifikasi bakteri asam laktat (BAL) yang ditemukan dengan menggunakan buku petunjuk identifikasi Bergey's (1994) dan Cowan (1974). Penelitian ini menggunakan tiga wadah pemeliharaan yang diberi sumber karbon mollase dengan jumlah karbon yang sama, yaitu $48 \mathrm{~g}$. Adapun kode sampel pada wadah yang digunakan, yaitu:

$\mathrm{BU}_{1}$ : Sumber karbon mollase 1

$\mathrm{BU}_{2}$ : Sumber karbon mollase 2

$\mathrm{BU}_{3}$ : Sumber karbon mollase 3

\section{Persiapan Wadah Budidaya dengan Sistem Bioflok}

Wadah yang digunakan pada penelitian ini adalah bak fiber. Bak dicuci bersih terlebih dahulu dan dikeringkan untuk menghindari adanya bibit penyakit, kemudian diisi dengan air payau salinitas 17 ppt sebanyak 150 liter, air disterilisasi dengan pemberian kaporit selanjutnya air diaerasi selama 3 hari untuk menghilangkan kaporit di dalam air.

Probiotik yang diberikan pada air pemeliharaan, yaitu bakteri yang digunakan adalah bakteri Boster Multisel. Probiotik diberkan sebanyak $10 \mathrm{ml} / \mathrm{m}^{3}$ air pemeliharaan, penambahan bakteri probiotik dilakukan setiap 7 hari sekali (Putra et al., 2017). Pemberian sumber karbon berupa mollase dengan rasio C/N yang telah ditentukan, yaitu 20:1 dimana pemberian karbon sebanyak $48 \mathrm{~g}$ (Ismayana et al., 2012). Penambahan sumber karbon dilakukan setiap 7 hari sekali selama masa pemeliharaan.

\section{Persiapan Alat dan Bahan}

Persiapan alat dan bahan di laboratorium meliputi sterilisasi alat-alat yang akan digunakan, pembuatan media NA (Nutrient Agar), media NB (Nutrient Broth), media MRS (de Mann, Rogosa, Sharp) Agar, media TSIA (Triple Sugar Iron Agar), media SIM (Simon Indol Motility), media O/F, pembuatan larutan pengencer PBS, dan pembuatan larutan fisiologis $\mathrm{pH} 2, \mathrm{pH} 4$, dan $\mathrm{pH} 6$ dengan cara mencampurkan larutan $\mathrm{NaCl}$ dan $\mathrm{HCl}$ pekat sedikit demi sedikit sampai $\mathrm{pH}$ larutan fisiologis sesuai dengan $\mathrm{pH}$ yang diinginkan dengan menggunakan $\mathrm{pH}$ meter.

\section{Pengambilan Sampel untuk Identifikasi BAL dan Perhitungan Jumlah Kepadatan Bakteri}

Sampel yang diuji untuk identifikasi BAL berupa flok (gumpalan) yang diambil dari wadah budidaya ikan nila merah dengan cara mengambil flok sebanyak $5 \mathrm{~mL}$ dengan menggunakan tabung 
imhoff lalu dibawa ke laboratorium dan dilakukan isolasi serta pemurnian sebanyak 4 kali. Selama penelitian, pengambilan sampel untuk identifikasi BAL dilakukan sebanyak 3 kali, yaitu pada hari ke21, hari ke-28, dan hari ke-35 selama masa pemeliharaan.

Sampel yang diuji untuk perhitungan jumlah kepadatan bakteri berupa air dari wadah budidaya dengan cara mengambil air sebanyak $5 \mathrm{~mL}$ lalu dibawa ke laboratorium untuk dilakukan pengamatan total bakteri. Pengamatan total bakteri air dilakukan setiap tujuh hari sekali, yaitu pada hari ketujuh dengan waktu pengambilan sampel pada pagi hari.

\section{Isolasi Bakteri}

Isolasi bakteri merupakan pengambilan atau memindahkan mikroba dari lingkungannya di alam dan menumbuhkannya sebagai biakan murni dalam medium buatan (Dewi, 2008). Isolasi bakteri dilakukan secara aseptik di laminar flow dengan metode penggoresan, yaitu dengan mengambil sampel berupa flok sebanyak $1 \mathrm{~mL}$ di masukkan ke dalam tabung eppendorf yang berisi $1 \mathrm{~mL}$ larutan fisiologis $\mathrm{pH} 2, \mathrm{pH}$ 4,dan $\mathrm{pH} 6$ kemudian di vortex selama 1 menit lalu didiamkan selama 15 menit agar bakteri bisa beradaptasi terhadap $\mathrm{pH}$ lingkungan hidupnya. Isolasi bakteri ini dilakukan pada media agar MRS sebanyak 3 kali dan pada media NA 1 kali.

Pemurnian pertama dilakukan dengan cara mengambil sampel sebanyak $80 \mu 1$ dari tabung ependorf dengan menggunakan mikro pipet lalu diratakan dengan menggunakan spider pada media MRS, dan diinkubasi ke dalam inkubator selama 24 jam. Pada pemurnian kedua dan ketiga setelah bakteri tumbuh koloni yang menciri dan terpisah diinokulasikan kembali ke dalam media MRS dimurnikan dengan cara penggoresan. Pemurnian keempat bakteri yang tumbuh diinokulasikan kembali ke dalam media NA dengan cara mengambil satu koloni bakteri menggunakan jarum ose lalu dilakukan penggoresan. Bakteri yang benar-benar sudah murni kemudian dilakukan identifikasi bakteri untuk melihat jenis bakteri asam laktat yang didapatkan.

\section{Perhitungan Total Bakteri Air pada Bioflok yang Diberi Mollase}

Perhitungan total bakteri dilakukan dengan menggunakan larutan Mc Farland. Standar Mc Farland berada dalam bentuk skala yang bernomor dari 1 sampai 10 yang menjelaskan konsentrasi spesifik dari bakteri per mL. Sampel yang diambil untuk perhitungan total bakteri berupa air dari wadah budidaya dengan sistem bioflok sebanyak $5 \mathrm{~mL}$, kemudian sampel dibawa ke laboratorium untuk dilakukan perhitungan total bakteri nya.

Media NB terlebih dahulu dikeluarkan dari Refrigerator dan diletakkan di laminar flow. Setelah itu, air sampel sebanyak $100 \mu \mathrm{L}$ diambil dengan menggunakan mikropipet dan dimasukkan ke dalam tabung reaksi yang berisi media NB lalu divortex dan diinkubasi ke dalam inkubator selama 24 jam. Setelah 24 jam, sampel dikeluarkan dari inkubator dan disentrifuge selama 10 menit dengan kecepatan $5.000 \mathrm{rpm}$. Secara hati-hati keluarkan supernatant dengan pipet sampai hanya tersisa pellet, lalu PBS sebanyak $9 \mathrm{~mL}$ dimasukkan kedalam tabung reaksi dan divortex agar pellet dan larutan PBS homogen. Total bakteri didapat dengan cara membandingkan kekeruhannya secara visual sampel yang diamati dengan 1 set standar larutan Mc Farland.

\section{Identifikasi Bakteri}

Identifikasi bakteri berdasarkan karakteristik fenotip, yaitu morfologi dan biokimia. Pengamatan morfologi mengacu pada Cappucino dan Sherman (2001), meliputi bentuk, tepi, elevasi, warna dan ukuran koloni. Pengamatan morfologi sel mencakup bentuk, sifat gram dan motilitas di bawah mikroskop binokuler dengan perbesaran 1.000 kali. Identifikasi bakteri dilakukan dalam beberapa uji antara lain uji fisika (morfologi koloni), uji kimia (pewarnaan gram) dan uji biokimia (uji katalase, uji oksidase, uji O/F, uji SIM, dan uji $\mathrm{H}_{2} \mathrm{~S}$.

\section{Analisis Data}

Hasil yang didapatkan berdasarkan uji fisika, uji kimia dan uji biokimia dianalisis dengan menggunakan buku petunjuk identifikasi Cowan (1974) dan Bergey's (1994). Hasil data identifikasi bakteri yang diperoleh selama penelitian dianalisis secara deskriptif dan disajikan dalam bentuk tabel dan gambar. 


\section{HASIL DAN PEMBAHASAN}

\section{Hasil Isolasi Bakteri Asam Laktat (BAL) pada pH yang Berbeda}

Hasil inokulasi bakteri asam laktat (BAL) pada $\mathrm{pH} 4$ dan $\mathrm{pH} 6$ setelah dilakukan pemurnian sebanyak 4 kali ditemukan sebanyak 16 isolat yang dapat di identifikasi. Bakteri asam laktat (BAL) yang tumbuh pada $\mathrm{pH} 4$ sebanyak 8 isolat dan pada $\mathrm{pH} 6$ terdapat sebanyak 8 isolat juga. Semua isolat yang ditemukan merupakan isolat yang sudah murni ditandai dengan warna dan bentuk koloni yang terlihat seragam. Adapun hasil inokulasi bakteri asam laktat yang telah murni dapat dilihat pada Gambar 1 .

Jenis bakteri yang ditemukan dari wadah budidaya bioflok dengan penambahan sumber karbon mollase merupakan bakteri asam laktat (BAL) dimana bakteri tersebut dapat tumbuh baik pada $\mathrm{pH}$ rendah, yaitu pada $\mathrm{pH} 4$ dan $\mathrm{pH}$ 6. Pada $\mathrm{pH} 2$ tidak terdapat bakteri asam laktat satupun yang tumbuh karena kondisi lingkungan tumbuh bakteri yang terlalu asam. Hal ini sesuai dengan pendapat Jay et al. (2005), yang menyatakan bahwa $\mathrm{pH}$ terbaik untuk pertumbuhan bakteri asam laktat (BAL) adalah pada kisaran $\mathrm{pH} 3,2-6,9$. Apabila $\mathrm{pH}$ lingkungan tidak sesuai untuk aktivitas enzim bakteri secara optimal, maka mikroba tersebut tidak dapat melakukan metabolisme dengan baik akibatnya mikroba tidak dapat tumbuh dengan optimal selain itu, kondisi lingkungan bakteri yang terlalu asam akan menyebabkan terganggunya sistem kerja enzim dan berakibat pertumbuhan bakteri tidak optimal.

Enzim juga merupakan salah satu faktor yang mempengaruhi pertumbuhan dari bakteri asam laktat pada $\mathrm{pH}$ rendah. Bakteri asam laktat dapat tumbuh pada $\mathrm{pH}$ yang rendah juga dikarenakan bakteri ini memiliki enzim protease, yaitu aminopeptidase yang mampu mempengaruhi adaptasi dan pertumbuhan bakteri asam laktat pada kondisi asam. Enzim protease dibutuhkan oleh bakteri asam laktat untuk pertumbuhan dan menghasilkan asam seperti dalam proses fermentasi.

\section{Identifikasi Bakteri}

Pengamatan morfologi dari masing-masing isolat bakteri asam laktat yang ditemukan selama penelitian memiliki bentuk, warna dan morfologi koloni yang berbeda dikarenakan isolat yang ditemukan merupakan jenis yang berbeda. Isolat yang ditemukan setelah dilakukan pengamatan, memiliki koloni yang berwarna krem dan krem tua, bentuk koloni terdiri dari bulat besar dan bulat kecil, serta morfologi koloni berbentuk bulat, licin, datar serta cembung. Hasil pengamatan morfologi yang didapatkan selama penelitian sesuai dengan hasil penelitian Sarbaini (2015), yang menyatakan bahwa morfologi bakteri asam laktat ada yang berbentuk bulat besar dan bulat kecil, berwarna krem dan krem tua, serta berbentuk batang (Basil) dan bulat (Cocus) setelah dilakukan pewarnaan Gram. Dengan demikian, morfologi koloni dari ke-16 isolat yang ditemukan selama penelitian merupakan karakteristik dari kelompok bakteri asam laktat.

Berdasarkan isolat yang diamati, terdapat ke 16 isolat tergolong ke dalam bakteri Gram positif karena berwarna ungu setelah dilakukan pewarnaan Gram. Gambar 2 dibawah menunjukkan bahwa bakteri yang diamati tergolong bakteri Gram positif karena kemampuan dari bakteri dalam mengikat kristal violet sangat kuat. Berdasarkan pewarnaan Gram, dapat diketahui bahwa sel yang tidak dapat melepaskan warna kristal violet akan berwarna ungu yang disebut bakteri Gram positif sedangkan sel yang dapat melepaskan kristal violet dan mengikat safranin sehingga berwarna merah muda disebut bakteri Gram negatif.

Prinsip pewarnaan Gram adalah kemampuan dinding sel dalam mengikat zat warna dasar (kristal violet) setelah pencucian dengan alkohol. Keadaan ini berhubungan dengan komposisi senyawa penyusun dinding sel. Pada bakteri Gram positif mengandung peptidoglikan yang lebih banyak dibandingkan bakteri gram negatif (Syulasmi et al., 2005). Pada bakteri Gram positif setelah pelunturan warna dengan alkohol, sel akan mengalami dehidrasi dan terjadi pengerutan pori-pori. Hal ini menyebabkan permeabilitas membran sel bakteri turun dan kompleks kristal violet iodium tidak dapat keluar dari sel sedangkan pada bakteri gram negatif setelah pelunturan warna dengan alkohol, lemak akan dikeluarkan dari dinding sel akibatnya kristal violet iodium akan keluar dari sel. Menurut Fardiaz (1989) dalam Lisdayanti (2013), struktur dinding sel bakteri Gram positif 90\% terdiri dari lapisan peptidoglokan sedangkan pada bakteri Gram negatif memiliki lapisan luar dinding sel yang mengandung 5-10\% peptidoglikan.

Hasil dari pengamatan uji biokimia yang dilakukan selama penelitian didapatkan 2 genus bakteri asam laktat (BAL) yang terdapat pada flok dari wadah budidaya bioflok yang diberi sumber 
karbon mollase, yaitu genus Bacillus dan Streptococus. Adapun hasil dari pengamatan uji biokimia yang didapatkan selama penelitian dapat dilihat pada Tabel 1.

\section{Bacillus sp.}

Hasil identifikasi yang ditemukan selama penelitian berdasarkan hasil uji fisika, uji kimia, dan uji biokimia terdapat 11 isolat yang tergolong ke dalam kriteria genus Bacillus. Berdasarkan hasil identifikasi yang telah dilakukan, kriteria bakteri yang didapat sesuai dengan pendapat Hatmanti (2000), yang menyatakan bahwa warna koloni pada Bacillus umumnya berwarna krem terkadang krem tua, koloni berbentuk bulat dengan tepian licin, dan tidak mengkilat. Bentuk koloni dan ukurannya sangat bervariasi tergantung dari jenisnya dan pada umumnya memiliki ukuran $0,3-2,2$ $\mu \mathrm{m} \times 1,2-7,0 \mu \mathrm{m}$. Selain itu Bacillus sp. merupakan bakteri berbentuk batang, setiap jenis juga menunjukkan kemampuan dan ketahanan yang berbeda-beda dalam menghadapi kondisi lingkungannya, misalnya ketahanan terhadap panas, asam, kadar garam, dan sebagainya.

Peran Bacillus dalam budidaya dengan sistem teknologi bioflok, memiliki berbagai keuntungan. Menurut Irribaren et al. (2012), bakteri ini mampu menjadi solusi untuk meningkatkan pertumbuhan pada ikan, efisiensi pakan, kecernaan pakan, meningkatkan efektivitas enzim-enzim dalam pencernaan, menghambat bakteri patogen berbahaya dan meningkatkan sistem imun tubuh. Bacillus sp. diyakini mampu meningkatkan daya cerna ikan karena bakteri ini mampu berkompetisi dengan bakteri patogen dalam mendapatkan nutrisi dan ruang permukaan dinding usus ikan sehingga pertumbuhan bakteri patogen pun akan terhambat.Streptococus sp.

Hasil identifikasi yang ditemukan selama penelitian berdasarkan hasil uji fisika dan uji biokimia terdapat 5 isolat yang tergolong ke dalam kriteria genus Streptococus. Secara umum, bakteri ini memiliki karakteristik berbentuk cocus, membentuk koloni bundar kecil, Gram positif, katalase negatif, non motil, bakteri ini tidak membentuk spora dan tergolong bakteri asam laktat. Diameter dari bakteri ini pada umumnya berukuran $0,7-1,4 \mu \mathrm{m}$.

Menurut Wijaya (2014), Streptococus merupakan salah satu genus yang termasuk ke dalam kelompok bakteri asam laktat. Jenis ini merupakan salah satu bakteri probiotik dan telah digunakan dalam bidang akuakultur untuk mengontrol berbagai penyakit, sebagai suplementasi atau bahkan dalam mengganti penggunaan senyawa-senyawa antimikrobial. Beberapa jenis dari genus Streptococus yang merupakan tergolong bakteri asam laktat, yaitu Streptococus faecalis, Streptococus thermophilus, Streptococus lactis, Streptococus cremoris dan Streptococus liquefaciens. Bakteri ini dapat hidup pada kadar $\mathrm{pH}$ berkisar 4-7 dan suhu optimum pertumbuhan berada di $37^{\circ} \mathrm{C}$.

\section{Jumlah Kepadatan Bakteri Air pada Bioflok yang Diberi Mollase}

Sistem teknologi bioflok memerlukan bantuan sumber karbon sebagai sumber makanan dari bakteri tersebut. Penambahan sumber karbon mollase mempengaruhi kepadatan bakteri yang terdapat dalam wadah. Hal ini dikarenakan mollase merupakan gula dalam bentuk sederhana sehingga dapat dengan mudah dimanfaatkan oleh bakteri untuk pertumbuhanya. Adapun kurva jumlah kepadatan bakteri air dapat dilihat pada Gambar 3.

Pertumbuhan bakteri air yang didapat sesuai dengan acuan menurut Willey et al. (2009), yang menyatakan bahwa pertumbuhan bakteri mengalami beberapa fase, yaitu fase lag (fase lambat atau lag phase), fase pertumbuhan eksponensial (fase pertumbuhan cepat atau log phase), fase stationer (fase statis atau stationary phase) dan fase penurunan populasi (decline). Perubahan kemiringan pada kurva tersebut menunjukkan transisi dari satu fase perkembangan ke fase lainnya. Fase-fase tersebut mencerminkan keadaan bakteri dalam kultur pada waktu tertentu.

Putra et al. (2014), menyatakan bahwa kelimpahan bakteri yang tertinggi pada pengamatan hari ke -21 ini dikarenakan banyak bahan organik yang terdapat dalam air, berbeda dengan hari selanjutnya dikerenakan bahan organik yang sudah berkurang. Berdasarkan kurva di atas terlihat jumlah kepadatan bakteri semakin menurun setelah minggu ketiga karena diduga bakteri yang tersuspensi dalam air membentuk flok-flok bakteri, sehingga kelimpahan bakteri yang terukur dari air mengalami penurunan. Flok bakteri yang semakin banyak inilah yang mengakibatkan bakteri dan partikel bahan organik mengendap sehingga tidak terambil ketika dilakukan pengambilan sampel, sampai pada minggu ketiga terlihat kelimpahan bakteri terus meningkat, kondisi tersebut dipengaruhi oleh akumulasi bahan organik maka akan semakin besar pula total bakteri. 


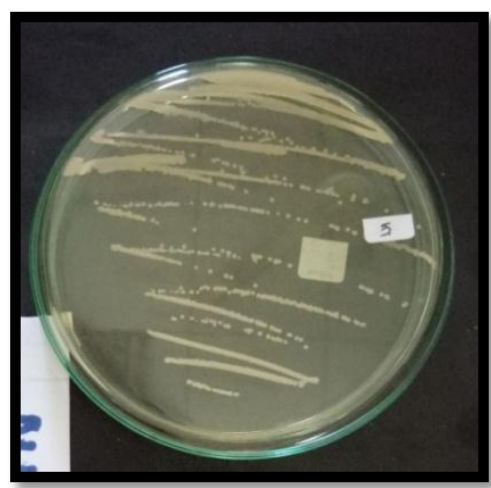

Gambar 1. Isolat Bakteri Asam Laktat (BAL) yang Sudah Murni

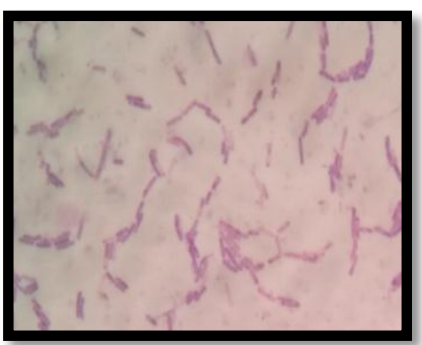

(a)

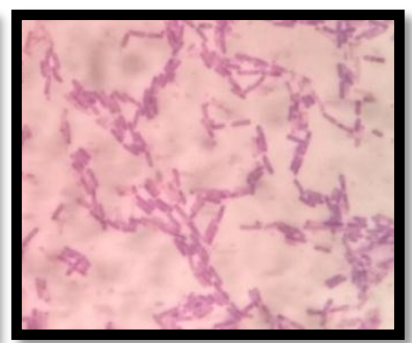

(b)

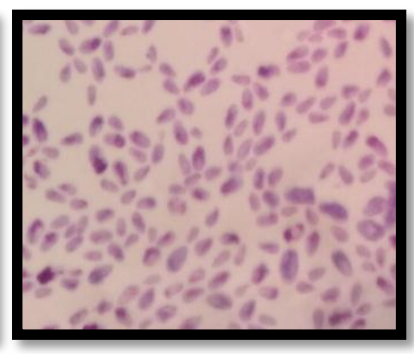

(c)

Gambar 2. Pewarnaan Gram dan Bentuk Bakteri

(a) Basil Berantai (Bacillus sp.); (b) Basil Mengelompok (Bacillus sp.); dan (c) Cocus (Streptococcus sp.)

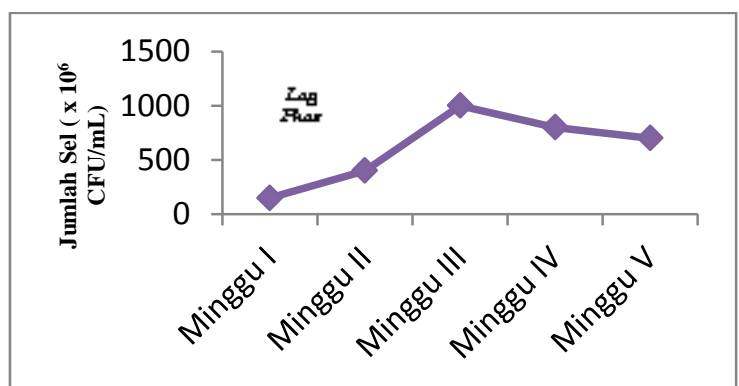

Gambar 3. Grafik Pertumbuhan Bakteri Air pada Bioflok yang Diberi Sumber Karbon Mollase dalam skala Mc. Farland

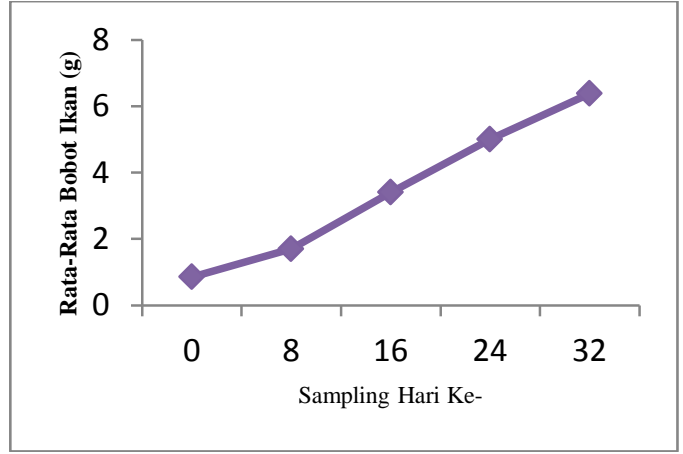




\section{Gambar 4. Grafik Pertumbuhan Bobot Rata-Rata Ikan Nila Merah}

Tabel 1. Hasil Uji Biokimia

\begin{tabular}{|c|c|c|c|c|c|c|c|}
\hline Kode Isolat & Katalase & Oksidase & $\mathrm{H}_{2} \mathrm{~S}$ & Motilitas & $\mathrm{O} / \mathrm{F}$ & $\begin{array}{l}\text { Acid } \\
\text { Fast }\end{array}$ & Genus \\
\hline M-4 ${ }_{1}$ & + & - & - & Non Motil & $-/+$ & + & Bacillus \\
\hline $\mathrm{M}-4_{2}$ & - & - & - & Non Motil & $-/+$ & + & Streptococus \\
\hline $\mathrm{M}-4_{3}$ & + & - & - & Non Motil & $-/+$ & + & Bacillus \\
\hline $\mathrm{M}-4_{4}$ & + & - & - & Non Motil & $-/+$ & + & Bacillus \\
\hline $\mathrm{M}-4_{5}$ & + & - & - & Non Motil & $-/+$ & + & Bacillus \\
\hline $\mathrm{M}-4_{6}$ & - & - & - & Non Motil & $-/+$ & + & Streptococus \\
\hline $\mathrm{M}-4_{7}$ & + & - & - & Non Motil & $-/+$ & + & Bacillus \\
\hline $\mathrm{M}-4_{8}$ & + & - & - & Non Motil & $-/+$ & + & Bacillus \\
\hline $\mathrm{M}-6_{1}$ & + & - & - & Non Motil & $-/+$ & + & Bacillus \\
\hline $\mathrm{M}-6_{2}$ & + & - & - & Non Motil & $-/+$ & + & Bacillus \\
\hline $\mathrm{M}-6_{3}$ & - & - & - & Non Motil & $-/+$ & + & Streptococus \\
\hline M-6 $6_{4}$ & - & - & - & Non Motil & $-/+$ & + & Streptococus \\
\hline $\mathrm{M}-6_{5}$ & + & - & - & Non Motil & $-/+$ & + & Bacillus \\
\hline$M-6_{6}$ & + & - & - & Non Motil & $-/+$ & + & Bacillus \\
\hline$M-6_{7}$ & + & - & - & Non Motil & $-/+$ & + & Bacillus \\
\hline$M-6_{8}$ & - & - & - & Non Motil & $-/+$ & + & Streptococus \\
\hline
\end{tabular}

Ket : M: Sumber karbon mollase, M- $4_{1}$ : Pada $\mathrm{pH} 4$ isolat pertama, M-6 $6_{1}$ : Pada $\mathrm{pH} 6$ isolat pertama $+=$ Positif, -: Negatif; o/f = Oksidatif negatif/Fermentati

Tabel 2. Hasil Pengukuran Kualitas Air

\begin{tabular}{ccccc}
\hline Wadah & \multicolumn{4}{c}{ Parameter Kualitas Air } \\
\cline { 2 - 5 } & $\begin{array}{c}\text { Suhu } \\
\left({ }^{\mathbf{o}} \mathbf{C}\right)\end{array}$ & $\mathbf{p H}$ & $\begin{array}{c}\text { DO } \\
(\mathbf{m g} / \mathbf{L})\end{array}$ & $\begin{array}{c}\text { Amonia } \\
(\mathbf{m g} / \mathbf{L})\end{array}$ \\
\hline $\mathrm{BU}_{1}$ & $26,3-27,8$ & $7,7-7,9$ & $6,0-6,8$ & $0,005-0,018$ \\
$\mathrm{BU}_{2}$ & $27,2-27$ & $7,8-7,9$ & $5,7-6,7$ & $0,004-0,063$ \\
$\mathrm{BU}_{3}$ & $26-28$ & $7,0-7,9$ & $5,9-6,8$ & $0,003-0,067$ \\
\hline
\end{tabular}

Ket: $\mathrm{BU}_{1}$ : Mollase ulangan 1, $\mathrm{BU}_{2}$ : Mollase ulangan 2, $\mathrm{BU}_{3}$; Mollase ulangan 3 


\section{Pertumbuhan Ikan Nila Merah Pada Bioflok yang Diberi Mollase}

Berdasarkan penelitian yang telah dilakukan selama 32 hari terhadap pertumbuhan ikan nila merah dengan sistem bioflok yang diberi sumber karbon mollase menunjukkan adanya peningkatan bobot di setiap minggunya. Pengukuran bobot rata-rata ikan nila merah dilakukan setiap 8 hari sekali. Pengamatan pertumbuhan bobot rata-rata ikan nila merah yang dilakukan selama penelitian dapat dilihat pada Gambar 4.

Pada Gambar 4 di atas dapat dilihat bobot rata-rata ikan nila merah di setiap minggunya mengalami peningkatan. Tingginya tingkat pertumbuhan ikan disebabkan karena adanya pengaruh sistem teknologi bioflok selama pemeliharaan. Budidaya dengan sistem teknologi bioflok secara umum memberikan keuntungan. Hal ini dikarenakan pada budidaya dengan sistem bioflok yang diberi sumber karbon mollase bakteri yang terdapat dalam wadah bertumbuh dengan baik dan membentuk flok (gumpalan) yang dapat dijadikan sebagai pakan tambahan bagi ikan nila merah. Hal ini sesuai dengan peryataan de Schryver et al. (2008), yang menyatakan bahwa adanya tambahan pakan alami pada media berasal dari asimilasi nitrogen dan karbon organik menjadi protein mikroba bakteri heterotrof yang telah ditambahkan ke dalam media pemeliharaan sehingga ikan dapat memaksimalkan pertumbuhannya dengan memanfaatkan flok yang terbentuk dari teknologi bioflok.

Pemberian sumber karbon mollase sangat mempengaruhi pertumbuhan ikan nila merah, hal ini disebabkan mollase merupakan gula sederhana sehingga dapat dengan mudah dimanfaatkan bakteri untuk mempercepat pertumbuhan.

\section{Kualitas Air}

Salah satu faktor yang sangat mempengaruhi pertumbuhan ikan adalah kualitas air. Kualitas air mempunyai peranan dalam menunjang pertumbuhan dan kelangsungan hidup ikan yang dipelihara. Pengamatan parameter kualitas air selama penelitian dilakukan setiap seminggu sekali. Pada penelitian ini kualitas air yang diukur adalah suhu, derajat keasaman ( $\mathrm{pH}$ ), dan oksigen terlarut (DO) dan amonia (NH3). Data hasil pengukuran kualitas air dapat dilihat pada Tabel 2.

Berdasarkan Tabel 2 di atas, hasil kualitas air yang didapat selama penelitian suhu berkisar antara 26$28^{\circ} \mathrm{C}$, nilai oksigen terlarut (DO) yaitu berkisar 5,7-6,8 $\mathrm{mg} / \mathrm{L}$, nilai $\mathrm{pH}$ yaitu berkisar 7,0-7,9 , dan nilai amoniak (NH3) yaitu berkisar 0,03-0,063. Nilai kualitas air selama penelitian dapat dikatakan sudah sesuai dengan pendapat Azim dan Little (2008), bahwa kualitas air pada media budidaya ikan nila dengan sistem bioflok yaitu suhu berkisar $26-30^{\circ} \mathrm{C}$, oksigen terlarut (DO) berkisar 3,0-7,5 mg/L, Amonia (NH3) berkisar 0,003- 0,114 dan pH berkisar 5,0-8,5.

Sopian et al. (2013), menyatakan bahwa pemeliharaan dengan sistem teknologi bioflok memberikan nilai lebih, yaitu kualitas air yang terkontrol segingga tidak perlu melalukan pergantian air lagi dibandingkan dengan pemeliharaan tanpa teknologi bioflok. Prinsip utama yang diterapkan dalam teknologi bioflok adalah manajemen kualitas air yang didasarkan pada kemampuan bakteri heterotrof untuk memanfaatkan $\mathrm{N}$ organik dan anorganik yang terdapat di dalam air melalui flok yang terdapat di dalam wadah pemeliharaan yang juga mampu menekan kadar amonia dalam air sehingga tidak mengalami peningkatan yang signifikan.

\section{KESIMPULAN}

Berdasarkan hasil identifikasi bakteri yang meliputi uji fisika, uji kimia, dan uji biokimia ditemukan 2 jenis bakteri asam laktat dari flok yang terbentuk dari teknologi bioflok yang diberi mollase, yaitu genus Bacillus dan Streptococcus. Bakteri asam laktat yang ditemukan tumbuh optimal pada $\mathrm{pH} 4$ dan 6 saja sedangkan pada $\mathrm{pH} 2$ tidak. Jumlah kepadatan bakteri air mencapai titik tertinggi pada minggu ketiga, yaitu dengan kepadatan rata-rata $10^{9} \mathrm{CFU} / \mathrm{mL}$. 


\section{REKOMENDASI}

Saran untuk penelitian selanjutnya, yaitu sebaiknya ilakukan identifikasi bakteri asam laktat dari flok yang terbentuk pada bioflok dengan menggunakan metode Polimerase Chain Reaction (PCR) agar hasil yang didapatkan lebih akurat dibandingkan dengan identifikasi bakteri secara konvensional.

\section{DAFTAR PUSTAKA}

Azim, M.E., Little,D. North, B. (2007). Growth and Welfare of Nile Tilapia (Oreochromis sp) Cultured Indoor Tank using BioFloc Tehnology (BFT). Presentation in Aquaculture 2007, 26 February - 3 March 2007. Sna Antonio, Texas, USA

Azim, M.E. Little, D.C. (2008). The biofloc technology (BFT) in indoor tanks: water quality, biofloc composition, and growth and welfare of Nile tilapia (Oreochromis niloticus). Aquaculture. 283, 29-35

Cappuccino, J.G. Sherman, N., (2001), "Microbiology: A Laboratory Manual”. New York: AddisonWesley Publishing Company

Cowan, S. J. (1974). Cowan and Steel's Manual for Identification of Medical Bacteria. 2nd Ed. Cambridge: Cambridge University Press

De Schryver, P., Crab, R., Defoirdt, T., Boon, N., Verstraete, W. (2008). The basics of bio-flocss technology: The added value for aquaculture. Aquaculture, 277, 125-137

Dewi, I. M. (2008). Isolasi Bakteri dan Uji Aktifitas Kitinase Termofilik Kasar dari Sumber Air Panas Tinggi Raja, Simalungun, Sumatera Utara. Tersedia dari Tesis. Sekolah Pascasarjana Universitas Sumatera Utara, Medan

Flores, M. L. (2011). The Use of Probiotic In Aquaculture: an overview. International Research Journal of Microbiology, 2, 471-478

Hatmanti, A. (2000). Penganalan Bacillus spp. Oseana, Vol. XXV, No.1, 200, 31-41

Iribarren, D., P. Dagá. M. T. Moreira., G. Feijoo. (2012). Potential environmental effects of probiotics used in aquaculture. Aquacult Int, 20, 779-789

Ismayana, A., Indrasti, N.S., Suprihatin, Akhhiruddin M., Aris.F., (2012). Faktor Rasio C/N Awal dan Laju Aerasi ada Proses CO-Composting Bagasse dan Blotong. Jurnal Teknologi Industri Pertanian, 22 (3), 173-179

Jay, J.M., M.J. Loessner. D.A. Golden. (2005). Modren Food Microbiology Seventh Edition. New York. Springer socience and Business Media. Inc

Lisdayati, Eka. (2013). Potensi Antibakteri Dari Bakteri Asosiasi Lamun (Seagrass) Dari Pulau Bonebatang Perairan Kota Makassar. Tersedia dari Fakultas Ilmu Kelautan Dan Perikanan Universitas Hasanuddin Makassar

Mulyana, D.Y. (2011). Kaya Raya dari Budidaya Ikan dengan Probiotik. Yogyakarta. Berlian media

Putra I, Rusliadi R, Fauzi. (2017). Growth Performance and Feed Unitilization of African Cat Fish Clarias gariepinus Feed Comercial Diet Reared the Biofloc System Enchanced with Probiotic

Putra, S.J. W., Nitisupardjo. M., and Widyorini. N,. (2014). Analisis Hubungan Bahan Organik Dengan Total Bakteri Pada Tambak Udang Intensif Sistem Semibioflok di BBPBAP Jepara. Diponegoro Journal of Maquares, 3, 121-129

Sarbaini. (2015). Isolasi Bakteri Kandidat Probiotik dari Usus Ikan Nila (Oreochromis niloticus) untuk Pengendalian Streptococcus agalactiae. Tersedia dari Pekanbaru: Universitas Riau

Sopian, A., Ikhsan K., Fajar Anggraeni. (2013). Pemanfaatan Bioflok dari Media Pendederan untuk Pemeliharaan Larva Udang Galah (Macrobrachuim rosenbergii). Widyariset, 16 (2), 277-232

Syulasmi, A., Hamdiyati, Y. Kusnadi. (2005). Petunjuk Praktikum Mikrobiologi

Wijaya, C. D. (2014). Identifikasi Dan Uji Aktivitas Antimikroba Bakteri Asam Laktat Yang Diisolasi Dari Rebung Kuning Bambu Betung Yang Difermentasi Pada Suhu 300 C. Tersedia dari Skripsi. Universitas Katolik Soegijapranata Semarang 
Willey, J.M., Sherwood, L.M., \& Woolverton, C.J., (2009), Prescott's Principles Of Microbiology. Boston: McGraw-Hill Higher Education 